\title{
Faculty Preparedness to Teach Students with Learning Disabilities: Developing an Instrument to Assess Faculty Perceptions
}

\author{
Kathryn D. Hansen, Debra L. Dawson, Jacqueline A. Specht \\ University of Western Ontario
}

\begin{abstract}
Despite increasing rates of entry, students with learning disabilities (LD) continue to face barriers to completing post-secondary education. Faculty attitudes and knowledge are important factors in supporting students with $L D$, yet little is known about faculty preparation. No valid, reliable, easyto-administer inventory exists to assess the perceptions of faculty about their preparedness for the task of teaching students with LD. The Faculty Preparedness Questionnaire (FPQ) was developed to measure faculty perceptions of preparedness for teaching students with LD based on two factors: knowledge and attitude. For this study, 101 community college instructors completed the original questionnaire consisting of 22 items. After factor analysis, the 17-item FPQ was determined to be a reliable and valid instrument for the measurement of instructor attitudes and knowledge as components of their perceptions of preparedness. This research contributes to the current dialogue regarding best practice for inclusive post-secondary education.
\end{abstract}

The number of students with diagnosed learning disabilities (LD) attending postsecondary education institutions across North America has been steadily increasing over the past decade (Cortiella \& Horowitz, 2014; Raue \& Lewis, 2011; Standing Senate Committee on Social Affairs, Science and Technology [SSCSAST], 2011). Statistics indicate that despite increasing rates of entry, students with LD continue to face barriers to completing their post-secondary programs (Finnie, Childs, \& Qui, 2012; Nichols, Harrison, McCloskey, \& Weintraub, 2002; Raue \& Lewis, 2011; SSCSAST, 2011). However, identifying and addressing barriers and providing adequate support to post-secondary students with LD have been associated with increased retention and 
success (Burgstahler \& Doe, 2004; Denhart, 2008). Students with disabilities have noted that faculty understanding of their learning needs is a key component to their success (Denhart, 2008; Getzel, 2008; Rao, 2004). Specifically, students with LD have described that faculty awareness about LD and faculty attitudes toward students with LD have affected their decisions to seek assistance, use accommodations, and persist with their post-secondary education (Denhart, 2008; Nichols et al., 2002; Tsargris \& Muirhead, 2012).

The incidence of LD in the general population is considered to be $5-10 \%$ (Learning Disability Association of Ontario, 2015; Kozey \& Siegel, 2008). Although the number of individuals diagnosed with LD enrolled in post-secondary programs has been increasing at all institutions, students with LD are more likely to attend two-year or community college programs due to the applied nature of learning in these institutions (Cortiella \& Horowitz, 2014; McCloy \& DeClou, 2013; Rath \& Royer, 2002; SSCSAST, 2001). Statistics in Ontario have indicated that approximately $13 \%$ of the overall student population at community colleges was registered with disability services and that nearly $40 \%$ of these students indicated that they had a LD (Government of Ontario, MTCU, 2011). Furthermore, some researchers have suggested that there are more students with LD than documented, due to the considerable number of students who choose not to disclose their LD or seek accommodations (Denhart, 2008; Gregg, 2007; Tsargris \& Muirhead, 2012). In post-secondary education, students with LD must self-disclose their disability diagnosis and assessment information in order to gain access to accommodations. Classroom and assessment accommodations are arranged individually through the campus disability services office (DSO). Appropriate accommodations provide students with LD the opportunity to meet their learning potential and achieve academic results reflective of their intellectual abilities (Tsargris \& Muirhead, 2012).

The definition of LD most often used by DSO counselors is referred to as the "discrepancy definition," which states that a student with a LD demonstrates academic achievement below that expected for his or her IQ. This underachievement is the result of a number of disorders, which may affect the acquisition, organization, or use of information and is not explained by other factors such as motivation, language learning, sensory impairments, or low cognitive function (American Psychiatric Association, 2013; Learning Disability Association of Ontario, 2011; Logan, 2009). Confounding the statistics and definition of LD is the comorbidity of other disorders, such as attentiondeficit disorder and/or mental illnesses. These comorbidities occur frequently with LD; however, the numbers are unclear due to inconsistent methods of data collection and analysis (Learning Disability Association of Ontario, 2015). Our study focuses on faculty preparedness to teach students who have LD as their main diagnosis.

Previous researchers have discussed the importance of faculty understanding the definition, the characteristics, and the needs of students with LD, as well as the negative impact that faculty misunderstandings have on student success (Denhart, 2008; Getzel, 2008). Denhart (2008) found the main reason that students hesitated to disclose their LD was fear of being misunderstood or misjudged by faculty. Given the increasing number of students with LD attending post-secondary institutions and the impact of faculty knowledge and attitudes on student retention and success, it is important to 
understand faculty perceptions of their preparedness to teach post-secondary students with LD.

\section{Preparation for Inclusion-Defining Knowledge and Attitude}

The importance of instructor preparation for teaching students with various types of disabilities in post-secondary education has been investigated in previous research (Burgstahler \& Doe, 2004; Cook, Rumrill, \& Tankersley, 2009; Getzel, 2008; Scott \& Gregg, 2000). Numerous studies have explored the attitudes, perceptions, and practices of university and college faculty toward students with disabilities (Jensen, McCrary, Krampe, \& Cooper, 2004; Lombardi \& Murray, 2011; Murray, Wren, \& Keys, 2008; Rao, 2004; Zhang et al., 2010), but these have not explicitly investigated faculty perceptions of their preparedness for inclusive classrooms in the post-secondary education sector (Hindes \& Mather, 2007). However, there are several studies exploring the determinants of teacher preparation for inclusion of students with disabilities in kindergarten-Grade12 education (Hay, Smit, \& Paulsen, 2001; Holdheide \& Reschly, 2008; Jordan, Schwartz, \& McGhie-Richmond, 2009; Sharma Forlin, Loreman, \& Earle, 2006; Sze, 2009). In the current study, we have adopted the definition of preparedness for inclusion as having the knowledge and attitudes needed to support an inclusive learning environment. Knowledge of disabilities has been considered an important underlying factor for a positive attitude and best practices in the classroom (Burgstahler \& Doe, 2004; Murray, Lombardi, Wren, \& Keys, 2009; Zhang et al., 2010) In addition, the term knowledge was intended to reflect an understanding of the basic definition of LD, what constitutes an LD and what does not, and that underachievement expressed by students with LD is not the result of lower intellect or reasoning abilities. We considered that instructor knowledge of LD would include understanding the needs of students with LD, common accommodations and the rationale for them, as well as classroom practices that best support these learners.

Knowledge is recognized as a structural component of attitude; and in consequence, increases in knowledge are thought to be associated with a greater influence of attitude on behaviour (Kassin, Fein, \& Markus, 2011). Attitudes are formed by exposure to the attitude object, the attitudes of others, and the process of learning, including information and knowledge. In the context of kindergarten-Grade 12 inclusive education, several researchers have shown that increasing teachers' knowledge about disabilities leads to more positive attitudes and beliefs about students with disabilities, which in turn affects their teaching practices. (Sharma et al., 2006; Sze, 2009). As a result, students with and without disabilities were found to be more successful in a positive, inclusive learning environment (Jordan et al., 2009). Sze (2009) stated that a positive teacher attitude toward students with disabilities was one of the most important predictors of a successful inclusive classroom. Underlying the willingness to embrace inclusion was teacher confidence based on preparation for the task of teaching students with disabilities. These studies demonstrated that teacher beliefs, knowledge, and attitudes about students with exceptionalities were all very closely linked, and teachers prepared with the right attitudes and skills were more likely to consistently promote inclusive education. In summary, preparation was a key factor in successful, inclusive education. 


\section{Measuring Faculty Perceptions of Students with Disabilities}

Researchers have investigated the knowledge, attitudes, and practices of university faculty regarding students with disabilities (Jensen et al., 2004; Lombardi \& Murray, 2011; Marquis et al., 2012; Murray et al., 2009; Murray et al., 2008; Vogel, Holt, Sligar, \& Leake, 2008; Zhang et al., 2010). These researchers were interested in how faculty perceived students with disabilities and in faculty willingness to provide services to these students; however, the links between attitude, knowledge, and preparation have remained unexplored. Questionnaires to measure faculty perceptions of students with disabilities have been created (Jensen et al., 2004; Murray et al., 2008), but none have been developed to distinctly measure faculty perceptions of their preparedness. Previous measures of knowledge or attitude either used lengthy instruments or measured knowledge and attitude toward all disability, and not specifically toward students with LD (Hindes \& Mather, 2007; Murray et al., 2008; Vogel, Leyser, Wyland, \& Brulle, 1999; Vogel et al., 2008; Zhang et al., 2010). For example, Vogel et al. (1999) developed a series of questionnaires to assess campus climate for students with disabilities from the perspectives of faculty, administrators, and students with and without various disabilities. In a longitudinal study, Vogel et al. (2008) used a faculty questionnaire to measure instructors' knowledge, practice, attitude, and expectations of students with disabilities, before and after a staff development intervention. Their questionnaire was a 35 -item instrument with five subgroups and some open-ended questions. They did not report the validity or reliability of the measure. In addition, Hindes and Mather (2007) used a 15-item questionnaire to investigate professor and peer attitudes toward students with various disabilities; however, they did not examine LD as a separate category. As a result, they have overlooked one of the largest populations of students with disabilities and their unique education needs. None of these previous studies distinctly explored knowledge and attitude in terms of faculty preparedness for teaching students with LD.

Faculty characteristics have also been the subject of investigation in regard to attitudes toward students with disabilities (Rao, 2004; Vogel, Leyer, Burgstahler, Sligar \& Zecker, 2006; Zhang et al., 2010). Variables such as age, gender, discipline, years of teaching, and academic rank have been studied. Vogel et al. (2006) and Zhang et al. (2010) found that none of these variables contributed significantly to faculty attitudes toward students with disabilities or classroom practices. Zhang et al. concluded that the important factors influencing faculty practices were faculty personal beliefs based on knowledge of disability issues and faculty beliefs about students' potential for success. In addition, Vogel et al. (2006) compared faculty knowledge about students with disabilities at three different types of American institutions - a state university, a private university, and a community college. They reported that although the private university had increased knowledge about disabilities and legislation, there were no differences between the public university and the community college faculty. Overall, there were no differences in faculty knowledge regarding providing accommodations to students with disabilities in the three different types of institutions.

In summary, the importance of faculty preparedness for the task of teaching students with LD has been articulated in previous studies. Knowing that faculty attitudes and practices contribute to the success or failure of students with $\mathrm{LD}$, researchers agree that 
understanding faculty attitudes and knowledge is valuable and should be utilized to develop and improve professional development plans (Hindes \& Mather, 2007; Lombardi \& Murray, 2011; Vogel et al., 2008). However, none of the previous researchers have offered a succinct, valid, and reliable instrument that specifically measures faculty perceptions of their preparedness. Since knowledge and attitude have been described as important constructs of preparedness (Hay et al., 2001; Sze, 2009), institutions of higher education need to have a process in place to facilitate the assessment of faculty knowledge and attitudes regarding teaching students with LD. Assessing faculty perceptions of their knowledge and attitudes about teaching students with LD will provide a clearer understanding of the gaps in educator preparation and subsequent areas for improvement. A valid and reliable instrument is needed to inform individual faculty members, faculty development centres, administrators, and student disability support offices about faculty preparedness in the ongoing efforts to improve educational success for post-secondary students with LD. The purpose of this study was to develop an instrument that measured faculty self-rated knowledge and attitudes as determinants of preparedness for teaching students with LD. As a result, we developed the Faculty Preparedness Questionnaire (FPQ) to specifically assess post-secondary educators' perceptions of preparedness for the task of teaching students with LD. We also conducted validity and reliability tests of the developed tool.

\section{Method}

\section{Participants}

We invited 424 full- and part-time instructors at a large community college in southwestern Ontario to complete an online or hard-copy questionnaire. The invitation was distributed through email and during a face-to-face semester start-up faculty meeting. The demographics of the overall college faculty population at the time of the survey were $53.5 \%$ female and $46.5 \%$ male, with an age range of 29-65 years and a median age of 45 years. Furthermore, the population of college faculty was $93 \%$ Caucasian; the $7 \%$ identifying as minorities were distributed as $1 \%$ Aboriginal, $0.7 \%$ Black, $1.8 \%$ South Asian, and $3.5 \%$ Arab. This categorization for collecting demographic data followed that used by the Canadian Labour Program using 10 categories of visible minorities, as well as a separate category for Aboriginal people (Government of Canada, 2008b). The data from this community college reflected a workforce slightly less diverse than the overall Canadian workforce population, which is stated as $16 \%$ visible minorities and $4 \%$ Aboriginal (Government of Canada, 2008a, 2008b). In addition, the highest level of education of the college faculty at the time of the study was $1 \%$ with a Doctoral degree, $37 \%$ with a Master's degree, $32 \%$ with a Bachelor's degree, and $28 \%$ with a collegelevel diploma. Previous investigators determined that the variables of age, gender, and faculty rank had no influence on faculty approaches to teaching students with disabilities (Rao, 2004; Vogel et al., 2006; Zhang et al., 2010); therefore, a hypothesis including the effect of socio-demographic factors on preparedness to teach students with LD was not included in the current study. 
Further demographic information collected from the sample in this study included the number of years of college teaching and the instructor's primary school of teaching. This demographic data was collected in order to describe our sample of participants and confirm that the sample reflected the greater college population in terms of years of teaching experience and discipline.

\section{Materials: Development of the Faculty Preparedness Questionnaire}

We developed the FPQ based on a thorough literature review of the available inventories that proposed to examine faculty perceptions of their knowledge and attitudes (Lombardi \& Murray, 2011; Murray et al., 2008; Murray et al., 2009; Vogel et al., 2008; Zhang et al., 2010). We noted the inventory items that were related to student success, and specifically related to faculty knowledge and attitude. As well, we drew on our personal expertise in the areas of inclusive education, faculty development, and postsecondary student success in order to select and create the questionnaire items. Further input from a college DSO manager helped confirm that the selected items were relevant to student success. Three items were designed in consultation with the DSO manager, who was familiar with the needs of students and instructors surrounding this issue. The wording of the items from previous questionnaires was changed to make it more relevant to the measurement of attitude and knowledge. As a result, the 22-item questionnaire (see Appendix) addressed themes such as knowledge of disability legislation, knowledge about LD and use of resources, attitudes toward students with LD, and perceptions of students with LD and their potential for success. In addition, two questions were used to collect the demographic information of interest: the number of years of college teaching and the instructor's primary school of teaching. The 22 items were designed with the two key dimensions in mind: instructor knowledge with respect to students with LD and their supports, including knowledge of the definition of LD and legislation (items \#1-9), and instructor attitude toward students with LD, including perceptions of students with LD and their potential for success (items \#10-22). A Likert-type scale with six values ranging from strongly agree to strongly disagree was used with the aim of generating a clear positive or negative response to each statement on the survey. For most items, a higher score indicated a more positive perception; however, items \# 10,11, 14, 16, 17, 19 , and 20 were worded using a reverse scale in order to reduce the chance of respondents answering habitually.

A small group of college instructors $(n=8)$ who were not part of the final data collection assessed the content validity of the FPQ. They completed the questionnaire in order to assess the wording and clarity of the items, along with overall content, the survey tool website access, and the time required to complete. As a result of their expert opinion, one of the demographic questions was changed. Originally we asked participants to select all of their schools of teaching within the college from a drop-down box, but because some instructors teach in more than one school, this would have limited any comparisons between groups; therefore, the question was changed so that participants selected their primary school of teaching. 


\section{Procedure}

After receiving approval for the study, we sent an email to all full- and part-time faculty at a large community college inviting them to participate. The email was sent out twice over a 6-week time period in February to March, 2012. The letter of information and consent form were attached to the invitation to participate. The respondents were directed in the email to open the link to the survey tool website, which then opened the questionnaire.

\section{Data Analysis}

Quantitative data analysis was conducted using SPSS software (version 20). Descriptive statistics were generated for all of the variables. Exploratory factor analysis and internal reliability scores (Cronbach's alpha) were used to determine the contribution of each variable to the two factors proposed in the questionnaire: knowledge and attitude. The factor analysis verified that the items developed belonged to two sub-scales, so they could be used for further analysis. A one-way ANOVA was conducted to determine whether there were differences in knowledge and attitude scores between groups based on the number of years of teaching.

The Likert-scale scores from the questionnaire were imported from the survey spreadsheet to SPSS and visually screened for missing data and tested for normalcy. The missing data were less than $5 \%$ and did not form a pattern; therefore, they were considered to be at random (Field, 2005). The missing data were replaced with the mean value for the item, as Field (2005) suggested that this is a good option when the variables are normally distributed and the sample size needs to be preserved. Also, in order to align the item scoring so that a higher score indicated a more positive attitude, the reversed scale item scores were reversed using SPSS.

\section{Results}

We received 103 responses through the online format and none by hard copy. Of the 103 responses, two did not answer more than the demographic questions and were removed from the sample. The remaining 101 respondents were retained for further statistical analysis resulting in a $23.8 \%$ response rate. The respondents ranged in their number of years of teaching from 0.5 to over 40 , with a mean of 12.7 years $(S D=9.2)$. All schools of study were represented, and the sample was considered to be proportionally representative of the overall college faculty population in terms of the number of years of college teaching and teaching disciplines. The demographic data for participants by school of study is reported in Table 1. To explore whether years of teaching impacted the attitude and knowledge scores, participants were further divided into three categories based on years of teaching: Early career $(0-5$ years $) n=28$; midcareer (6-15 years), $n=36$; and late career ( $15+$ years), $n=34$. 


\section{Table 1}

The Number of Participants and Proportional Representation by School of Study

\begin{tabular}{lccc}
\hline School of Study & $\begin{array}{c}\text { Number of } \\
\text { Questionnaire } \\
\text { Participants }\end{array}$ & $\begin{array}{c}\text { Number of } \\
\text { Faculty }\end{array}$ & $\begin{array}{c}\text { \% of Faculty that } \\
\text { Participated in } \\
\text { the Study }\end{array}$ \\
\hline Business, Media Arts & 21 & 78 & 26.9 \\
Community Studies & 29 & 125 & 23.2 \\
Health Sciences & 11 & 45 & 24.4 \\
Nursing & 18 & 74 & 24.3 \\
Engineering \& Skilled Trades & 19 & 102 & 18.6 \\
Undeclared & 3 & - & - \\
Overall & 101 & 424 & 23.8 \\
\hline
\end{tabular}

\section{Construct Validity Testing}

The construct explored in this research study was "preparedness"-specifically, faculty preparedness for teaching students with LD. For this purpose, preparedness was considered to have two contributing factors: knowledge (about LD and strategies that support students with LD) and attitude (regarding students with LD and their potential in the post-secondary setting). Following the steps outlined by Field (2005), exploratory factor analysis was performed on the data to determine whether the variables fit into the two factors as intended. First, a principal component analysis was performed using all 22 variables in order to look at the correlation matrix and to screen the variables for lack of correlation and singularity. In this data there was one variable, Time Spent, that did not correlate with any others $(r<.3)$, so it was removed. This variable represented item \#10 on the questionnaire and was worded, "I spend a disproportionate amount of time making teaching/testing accommodations and assisting students with disabilities in my courses."

Construct validity was further examined by factor analysis forcing two factors and using oblique rotation. The use of two factors was confirmed by the scree plot. Oblique rotation was chosen because theoretically the two factors, knowledge and attitude, are considered related constructs. Only items with loadings greater than 0.4 were retained for each construct. This resulted in the removal of two items. The variable Have Skills (item \#12: "I believe I have the skills necessary to teach students with learning disabilities") did not load clearly on only one factor; and the variable Advocates for Self (item \#21: "Students with learning disabilities are advocates for their learning") did not load on either of the two factors. Further to this analysis, reliability measured by Cronbach's alpha indicated that item \#13 ("The college is an accessible learning environment for students with learning disabilities") correlated poorly with the overall knowledge score $(r=.19)$. Consequently, this item was removed to improve the convergent validity and internal reliability of the sub-scale. As a result, Cronbach's alpha for the knowledge inventory increased from .78 to .82 . 
Table 2

Items from the FPQ and Their Loadings on the Pattern Matrix of Final Factor Analysis

\begin{tabular}{|c|c|c|c|}
\hline & Questionnaire Item & $\begin{array}{l}\text { Comp. } 1 \\
\text { Attitude }\end{array}$ & $\begin{array}{c}\text { Comp. } 2 \\
\text { Knowledge }\end{array}$ \\
\hline 1 & I understand the term "learning disability." & -.061 & .639 \\
\hline 2 & $\begin{array}{l}\text { I have a strong understanding of the needs of students with } \\
\text { learning disabilities. }\end{array}$ & -.152 & .824 \\
\hline 3 & $\begin{array}{l}\text { I understand my legal responsibility as an instructor to provide } \\
\text { accommodations for a student with a learning disability. }\end{array}$ & -.183 & .773 \\
\hline 4 & $\begin{array}{l}\text { I include a statement on my syllabus that encourages students to } \\
\text { meet with me to discuss their accommodation and learning needs. }\end{array}$ & .068 & .406 \\
\hline 5 & $\begin{array}{l}\text { I make a verbal statement on the first day of class inviting students } \\
\text { with disabilities to meet with me to discuss their learning needs. }\end{array}$ & .301 & .514 \\
\hline 6 & $\begin{array}{l}\text { I have attended specialized training to acquire knowledge about } \\
\text { students with learning disabilities and/or how to teach them. }\end{array}$ & .351 & .501 \\
\hline 7 & $\begin{array}{l}\text { I am aware of assistive technology that students with learning } \\
\text { disabilities can use to improve their performance in my course. }\end{array}$ & .183 & .598 \\
\hline 8 & $\begin{array}{l}\text { Tests and other assessments that I administer in my courses are } \\
\text { created with the diverse learning needs of students in mind. }\end{array}$ & .225 & .500 \\
\hline 9 & $\begin{array}{l}\text { If I have a question about a student with a learning disability or their } \\
\text { accommodation plan I would go to Student Services to seek support. }\end{array}$ & .024 & .520 \\
\hline 11 & $\begin{array}{l}\text { Providing classroom and testing accommodations to students with } \\
\text { learning disabilities is unfair to students without learning disabilities }\end{array}$ & .766 & -.081 \\
\hline 14 & $\begin{array}{l}\text { Accommodations for students with learning disabilities } \\
\text { compromise the integrity of the curriculum }\end{array}$ & .747 & .125 \\
\hline 15 & $\begin{array}{l}\text { I believe students with learning disabilities can be successful at } \\
\text { the college level. }\end{array}$ & .598 & .194 \\
\hline 16 & $\begin{array}{l}\text { Students with learning disabilities may be able to do the school } \\
\text { work using their accommodations but I am concerned that they } \\
\text { will they will have trouble in the real work place. }\end{array}$ & .680 & -.006 \\
\hline 17 & $\begin{array}{l}\text { I find students with learning disabilities wait until they are not } \\
\text { doing well in class to come and talk to me and then I question } \\
\text { whether they truly have a LD. }\end{array}$ & .718 & -.103 \\
\hline 18 & $\begin{array}{l}\text { Professionals with learning disabilities may be as effective as } \\
\text { professionals without LD in the same job/ occupation. }\end{array}$ & .477 & .105 \\
\hline 19 & $\begin{array}{l}\text { Students with a learning disability use it as an excuse when they } \\
\text { are not doing well in my class. }\end{array}$ & .779 & .011 \\
\hline 20 & $\begin{array}{l}\text { Having students with learning disabilities in the classroom } \\
\text { reduces the quality of the education that other students receive. }\end{array}$ & .648 & -.006 \\
\hline
\end{tabular}

Note: Factor loadings > .40 are in boldface. FPQ= Faculty Preparedness Questionnaire. Researchers wishing to use the Faculty Preparedness Questionnaire can contact the author for permission at khansen7@uwo.ca. 
The factor analysis was subsequently repeated on the remaining 18 items. At this point the factor structure was not retained, as the variable Support from Student Services (item \#22: "I feel that I can get adequate support from Disability Services about students with learning disabilities") loaded $<.40$ on both factors and was therefore removed as well. This left 17 items for the final factor analysis. This final factor analysis resulted in the two intended factors being confirmed, with eight variables clearly loading on the attitude factor and nine variables loading on the knowledge factor. Table 2 displays the questionnaire item and factor loadings for each item retained, as determined by the factor analysis. Figure 1 shows the component plot illustrating the clear loading of the 17 variables on the two factors: As in the factor analysis, Component 1 is attitude and Component 2 is knowledge. The total variance explained by the two factors was $45.28 \%$.

The Kaiser-Meyer-Olkin measure of sampling adequacy $(\mathrm{KMO}$ value $=.81$ ) determined that the variables clustered such that factor analysis was considered an appropriate tool, and indicated that factor analysis would produce robust results. In addition, Bartlett's test of sphericity was statistically significant at $p<.001(d f=171)$, indicating that expected correlations existed between the variables and that correlations were unlikely to have occurred by chance.

\section{Figure 1. Component Plot Showing Two Distinct Factor Groupings}

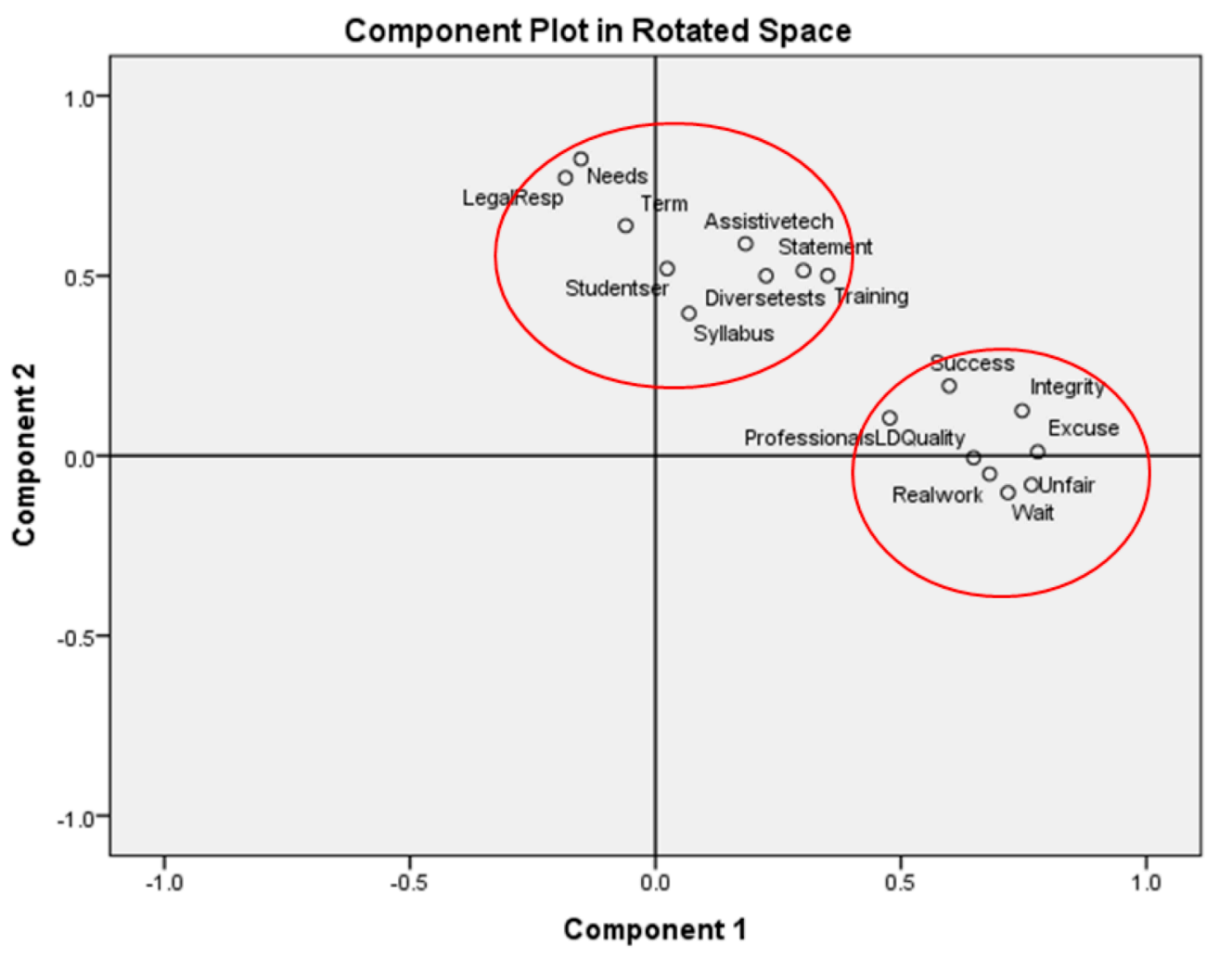

Reliability testing showed that the Cronbach's alpha for the knowledge sub-scale was good $(\alpha=.82)$, with item correlations in the range .38-.65. Similar results were obtained for the attitude scale $(\alpha=.86$; item correlations $=.49-.74)$. Factor correlation, 
$r=.39$, demonstrated that the two factors, knowledge and attitude, were correlated as expected.

The participant scores for each of the two sub-scales (knowledge and attitude) were then calculated. The mean overall score for the knowledge sub-scale was 4.23 $(S D=0.86)$, and the mean overall score for the attitude sub-scale was $4.33(S D=0.76)$.

\section{ANOVA: Years of Teaching}

Mean scores and standard deviations for each group are displayed in Table 3. The one-way ANOVA conducted to explore the differences between these groups found no significant differences. The f-scores are displayed in Table 3.

Table 3

Mean Knowledge and Attitude Scores by Years of Teaching

\begin{tabular}{cccccc}
\hline Factors & $\begin{array}{c}\text { Early career } \\
\mathbf{0 - 5} \text { years } \\
(\boldsymbol{n}=\mathbf{2 8})\end{array}$ & $\begin{array}{c}\text { Mid-career } \\
\mathbf{6 - 1 5} \text { years } \\
(\boldsymbol{n}=\mathbf{3 6})\end{array}$ & $\begin{array}{c}\text { Late career } \\
>\mathbf{1 1 5} \text { years } \\
(\boldsymbol{n}=\mathbf{3 4})\end{array}$ & $\boldsymbol{F},(\boldsymbol{d} \boldsymbol{f})$ & $\boldsymbol{p}$ \\
\hline $\begin{array}{c}\text { Knowledge } \\
M(S D)\end{array}$ & $4.52(0.61)$ & $4.20(0.85)$ & $4.32(0.62)$ & $1.61(2,95)$ & .205 \\
$\begin{array}{c}\text { Attitude } \\
M(S D)\end{array}$ & $4.51(0.85)$ & $4.19(0.87)$ & $4.08(0.79)$ & $2.11(2,95)$ & .126 \\
\hline
\end{tabular}

\section{Discussion}

The purpose of this study was to develop a valid and reliable instrument for measuring college faculty perceptions of their preparedness to teach students with LD. We wanted to build on the previous instruments available in the literature (Murray et al., 2008; Murray et al., 2009; Zhang et al., 2010), but specifically develop an instrument to measure the concept of preparedness: having the knowledge and attitudes to teach students with LD. It is important to have a tool to assess faculty preparedness for teaching students with LD because we know that faculty knowledge and attitudes toward students with LD provide an important contribution to effective, inclusive, and accessible postsecondary education (Black, Weinburg, \& Brodwin, 2014; Denhart, 2008; Getzel, 2008; Marquis et al., 2012; Nichols et al., 2002; Rao, 2004). Assessing faculty preparedness to meet the needs of the increasing number of students with LD is one way we can gauge our readiness to accommodate diverse learners in the post-secondary setting.

This study resulted in the development of the Faculty Preparedness Questionnaire (FPQ). The instrument was originally composed of 22 items (see Appendix); however, through principal component analysis five items were removed to improve the instrument construct validity and reliability. The structure of two sub-scales (knowledge sub-scale and attitude sub-scale) was verified by factor analysis and strong internal reliability measurements. The items remaining on the knowledge sub-scale assess faculty knowledge about the definition of LD, legislation requirements, and common strategies used to support students with LD, such as assistive technology. The items on the attitude sub-scale relate to faculty perceptions of the capability of students with LD in both school 
and the workplace, and to their beliefs about the fairness and impact of accommodations. The five items that were removed were likely the result of varied interpretation of the item wording by the respondents. For example, in item \# 10, ("I spend a disproportionate amount of time making teaching/testing accommodations and assisting students with disabilities in my courses") the interpretation of the phrase "a disproportionate amount of time" could have varied for the respondents. Furthermore, item \# 12 ("I believe I have the skills necessary to teach students with learning disabilities") loaded on both factors; perhaps this was because the term skills was used in the item, and therefore it did not clearly belong to either the knowledge or attitude sub-scale. After removal of the five items the final instrument proved to have robust reliability and construct validity, clearly measuring 17 items on the two sub-scales: knowledge and attitude.

The FPQ differs from previous instruments reported in the literature, as it has two clear sub-scales of preparedness. Previous instruments have not focused directly on preparedness (knowledge and attitude), and have used a greater number of items and more sub-scales (Murray et al., 2008; Vogel et al., 2008). On the other hand, the FPQ is succinct and purposeful; and we have reported the psychometrics on the FPQ, which will give researchers confidence in the instrument for future research.

As a result, the FPQ adds to the repertoire of faculty members, faculty developers, DSO personnel, and college administrators, by providing a measure of faculty perceptions of their preparedness for teaching students with LD. Moreover, the results of the current study will contribute to the expanding body of knowledge on faculty preparedness for inclusive post-secondary education by providing an instrument that can be used in future research in a variety of settings. We began by developing this instrument in the community college setting, as we know the number of students with LD attending community college is greater than that at the university level, making the role of instructor preparation even more important in this setting. The next step of this research will be to implement the FPQ in a multicentre study with a larger sample in order to further verify the instrument's validity and reliability. It would be most beneficial to administer the FPQ in a number of post-secondary institutions across North America, both community colleges and universities. The instrument was tested on a sample of community college educators with a wide range of teaching experience and content expertise. The results indicated that the years of teaching experience had no impact on knowledge or attitude scores, as there were no differences found between those in early career $(0-5$ years), mid-career (six-15 years) or later career ( $15+$ years) teaching. This aligns with the results found by Vogel et al. (2006). Faculty characteristics such as rank and discipline were not examined in this study, since previous research has shown that knowledge or attitudes toward students with disabilities did not vary significantly based on faculty characteristics. However, this could be confirmed in future research by using the FPQ, particularly given the increasing number of non-tenure-track and parttime faculty currently employed in post-secondary settings.

One limitation of this study is that it was conducted at only one large community college in Ontario, Canada. Although the sample size was adequate for the statistical analyses employed in this study, it is necessary to further verify the validity and reliability of the FPQ by extending the research into other regions of North America. Without extending this research into other college and universities across North America, the 
generalizability of the results remain limited. Nonetheless, the current instrument is an important step forward in developing an instrument to adequately assess faculty perceptions of their preparedness to teach the growing number of post-secondary students with LD.

\section{Implications for Practice}

The development of the FPQ can benefit many stakeholders in the post-secondary education system. First of all, educators in the system can use the questionnaire to examine their own ideas about preparedness for teaching students with LD, and can subsequently reflect on their understanding of and attitudes toward the increasing number of students with LD. Secondly, DSOs and faculty development offices will find the FPQ helpful for collecting information when developing education and training campaigns for both new and experienced faculty. Knowledge impacts attitudes, which subsequently inform our practices as educators. Burgstahler and Doe (2004) and Denhart (2008) recommended that faculty receive training about disability, relevant legislation, and use of accommodations while maintaining academic standards, as well as teaching strategies that increase student-faculty communication. They concluded that improving this subset of skills can improve the educational and career outcomes of students with disabilities. Knowing whether faculty perceptions are reflective of an accurate understanding of students with LD and of the strategies for teaching them will be helpful when developing faculty training materials. If faculty perceive that they are knowledgeable about LD, they will be less likely to seek information and training. The FPQ can provide the first step in this process, and faculty development professionals can build awareness campaigns accordingly. Addressing faculty preparation needs could take the form of workshops, online learning modules, or individual consultation sessions; creative forms of information dissemination should be encouraged. Further research could investigate the impact of such campaigns using the FPQ in a pre-post research design. Future studies could also use the FPQ to investigate correlations between participation in training and actual practices of faculty or student outcomes.

Finally, as more students with LD attend post-secondary education, it becomes increasingly important for administrators and educators to recognize the impact of being prepared for the diverse learning needs of students. If faculty are not well prepared, it is unlikely that barriers to academic success will be addressed or that students will be adequately supported in their learning. Using the FPQ, post-secondary institutions can assess their current and future needs with respect to best practices in delivering quality inclusive education.

\section{References}

American Psychiatric Association. (2013). Diagnostic and statistical manual of mental disorders (5th ed.). Washington, DC: Author.

Black, R. D., Weinburg, L. A., \& Brodwin, M. B. (2014). Universal Design for instruction and learning: A pilot study of faculty instructional methods and attitudes related to students with disabilities in higher education. Exceptionality Education International, 24(1), 48-64.

Burgstahler, S., \& Doe, T. (2004). Improving post-secondary outcomes for students with disabilities: Designing professional development for faculty. Journal of Post-secondary Education and Disability, 18, 135-147. 
Cook, L., Rumrill, P., \& Tankersley, M. (2009). Priorities and understanding of faculty members regarding college students with disabilities. International Journal of Teaching and Learning in Higher Education, 21, 84-96.

Cortiella, C., \& Horowitz, S. H. (2014). The state of learning disabilities: Facts, trends and emerging issues. New York, NY: National Center for Learning Disabilities.

Denhart, H. (2008). Deconstructing barriers: Perceptions of students labeled with learning disabilities in higher education. Journal of Learning Disabilities, 41, 483-497.

Field, A. (2005). Discovering statistics using SPSS (2nd ed.). Thousand Oaks, CA: Sage Publications.

Finnie, R., Childs, S., \& Qui, T. (2012). Patterns of persistence in postsecondary education: New evidence for Ontario. Toronto, ON: Higher Education Quality Council of Ontario.

Getzel, E. (2008). Addressing the persistence and retention of students with disabilities in higher education: Incorporating key strategies and supports on campus. Exceptionality, 16, 207-219.

Government of Canada. (2008a). Aboriginal peoples: 1 - Aboriginal ancestry (14), area of residence (6), age groups (8), sex (3) and selected demographic, cultural, labour force, educational and income characteristics (227A), for the total population. In 2006 Census: Data Products: Special Interest Profiles. Ottawa, ON: Author. Retrieved from: http://www12.statcan.gc.ca/census-recensement/2006/dp-pd/prof/sip/index-eng.cfm

Government of Canada. (2008b). Labour: 2 - Occupation - National Occupational Classification for Statistics 2006 (720C), sex (3) and selected demographic, cultural, labour force, educational and income characteristics (273) for the population 15 years and over. In 2006 Census: Data Products: Special Interest Profiles. Ottawa, ON: Author. Retrieved from: http://www12.statcan.gc.ca/census-recensement/2006/dp-pd/prof/sip/index-eng.cfm

Government of Ontario. (2011). Ministry of Training, Colleges and Universities: Update on students with disabilities [PowerPoint presentation]. In College Committee on Disability Issues, CCDI Provincial Meeting, February 3, 2011, Humber College: Minutes (Appendix A). Retrieved from http://www.disabilityissues.ca/english/Minutes\%20Document/CCDI\%20Minutes\%20Feb3\%202011.pdf

Gregg, N. (2007). Underserved and underprepared: Post-secondary learning disabilities. Learning Disabilities Research and Practice, 22, 219-228.

Hay, J. F., Smit, J., \& Paulsen, M. (2001). Teacher preparedness for inclusive education. South African Journal of Education, 21, 213-210.

Hindes, Y., \& Mather, J. (2007). Inclusive education at the post-secondary level: Attitudes of students and professors. Exceptionality Education Canada, 17(1), 107-128.

Holdheide, L. R., \& Reschly, D. J. (2008). Teacher preparation to deliver inclusive services to students with disabilities. Washington, DC: National Comprehensive Center for Teacher Quality.

Jensen, J. M., McCrary, N., Krampe, K., \& Cooper, J. (2004). Trying to do the right thing: Faculty attitudes toward accommodating students with learning disabilities. Journal of Postsecondary Education and Disability, 17, 81-90.

Jordan, A., Schwartz, E., \& McGhie-Richmond, D. (2009). Preparing teachers for inclusive classrooms. Teaching and Teacher Education, 25, 535-542.

Kassin, S., Fein, S., \& Markus, H. R. (2011). Social psychology. Belmont, CA: Wadsworth.

Kozey, M., \& Siegel, L. S. (2008). Definitions of learning disabilities in Canadian provinces and territories. Canadian Psychology, 49, 162-171.

Learning Disability Association of Ontario. (2011). Official definition of LDs [Webpage]. Retrieved from www.ldao.ca/introduction-to-ldsadhd 
Learning Disability Association of Ontario. (2015). What are LDs? [Webpage]. Retrieved from http://www.ldao.ca/introduction-to-ldsadhd/what-are-lds

Logan, J. (2009). Learning disabilities: A guide for faculty at Ontario universities (Academic colleagues working paper). Toronto, ON: Council of Ontario Universities. Retrieved from http://cou.on.ca/papers/learning-disabilities-a-guide-for-faculty-at-ontario-universities

Lombardi, A. R., \& Murray, C. (2011). Measuring university faculty attitudes toward disability: Willingness to accommodate and adopt Universal Design principles. Journal of Vocational Rehabilitation, 34, 43-56.

Marquis, E., Jung, B., Fudge-Schormans, A., Vajoczki, S., Wilton, R., Baptiste, S., \& Joshi, A. (2012). Creating, resisting or neglecting change: Exploring the complexities of accessible education for students with disabilities. The Canadian Journal for the Scholarship of Teaching and Learning, 3, Art 2. doi:10.5206/cjsotl-rcacea.2012.2.2

McCloy, U., \& DeClou, L. (2013). Disability in Ontario: Postsecondary education participation rates, student experience and labour market outcomes. Toronto, ON: Higher Education Quality Council of Ontario.

Murray, C., Lombardi, A., Wren, C., \& Keys, C. (2009). Associations between prior disabilityfocused training and disability-related attitudes and perceptions among university faculty. Learning Disability Quarterly, 32, 87-100.

Murray, C., Wren, C. T., \& Keys, C. (2008). University faculty perceptions of students with learning disabilities: Correlates and group differences. Learning Disability Quarterly, 31, 95-113.

Nichols, E., Harrison, A., McCloskey, L., \& Weintraub, L. (2002). Learning Opportunities Task Force, 1997-2002: Final Report. Richmond Hill, ON: Learning Opportunities Task Force.

Rao, S. (2004). Faculty attitudes and students with disabilities in higher education: A literature review. College Student Journal, 38, 191-198.

Rath, K. A., \& Royer, J. M. (2002). The nature and effectiveness of learning disability services for college students. Educational Psychology Review, 14, 353-381.

Raue, K., \& Lewis, L. (2011). Students with disabilities at degree-granting postsecondary institutions (NCES 2011-018). U.S. Department of Education, National Center for Education Statistics. Washington, DC: U.S. Government Printing Office.

Scott, S., \& Gregg, N. (2000). Meeting the evolving education needs of faculty in providing access for college students with LD. Journal of Learning Disabilities, 33, 158-167.

Sharma, U., Forlin, C., Loreman, T., \& Earle, C. (2006). Pre-service teachers' attitudes, concerns and sentiments about inclusive education: An international comparison of the novice pre-service teachers. International Journal of Special Education, 121(2), 80-93.

Standing Senate Committee on Social Affairs, Science and Technology (SSCSAST). (2011). Opening the door: Reducing barriers to post-secondary education in Canada. Ottawa, ON: Author. Retrieved from http://publications.gc.ca/site/eng/412186/publication.html

Sze, S. (2009). A literature review: Preservice teachers' attitudes toward students with disabilities. Education, 130, 53-56.

Tsargris, D., \& Muirhead, B. (2012). Evaluating post-secondary supports for Ontario students with learning disabilities. Toronto, ON: Higher Education Quality Council of Ontario.

Vogel, S. A., Holt, J. K., Sligar, S., \& Leake, E. (2008). Assessment of campus climate to enhance student success. Journal of Post-secondary Education and Disability, 21, 15-31. 
Vogel, S. A., Leyser, Y., Burgstahler, S., Sligar, S. R., \& Zecker, S. G. (2006). Faculty knowledge and practices regarding students with disabilities in three contrasting institutions of higher education. Journal of Postsecondary Education and Disability, 18(2), 109-121.

Vogel, S. A., Leyser, Y., Wyland, S., \& Brulle, A. (1999). Students with learning disabilities in higher education: Faculty attitude and practices. Learning Disability Research and Practice, 14, 173-186.

Zhang, D., Landmark, L., Reber, A., Hsu, H.Y., Kwok, O., Benz, M. (2010). University faculty knowledge, beliefs and practices in providing reasonable accommodations to students with disabilities. Remedial and Special Education, 31, 276-286.

\section{Authors' Note}

Correspondence concerning this article should be addressed to Kathryn Hansen. Email: khansen7@uwo.ca

\section{Appendix: Instructor Preparedness Questionnaire (original version)}

Please indicate your number of years of college teaching experience:

Indicate the programs in which you currently teach: [drop-down box in online version]

Please rate each of the following statements according to this 6-point scale:

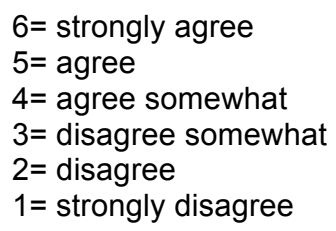

strongly strongly

agree disagree

\begin{tabular}{|c|c|c|c|c|c|c|}
\hline 1. I understand the term "learning disability." & 1 & 2 & 3 & 4 & 5 & 6 \\
\hline $\begin{array}{l}\text { 2. I have a strong understanding of the needs of } \\
\text { students with learning disabilities. }\end{array}$ & 1 & 2 & 3 & 4 & 5 & 6 \\
\hline $\begin{array}{l}\text { 3. I understand my legal responsibility as an instructor } \\
\text { to provide accommodations for a student with a } \\
\text { learning disability. }\end{array}$ & 1 & 2 & 3 & 4 & 5 & 6 \\
\hline $\begin{array}{l}\text { 4. I include a statement on my syllabus that } \\
\text { encourages students to meet with me to discuss } \\
\text { their accommodation and learning needs. }\end{array}$ & 1 & 2 & 3 & 4 & 5 & 6 \\
\hline $\begin{array}{l}\text { 5. I make a verbal statement on the first day of class } \\
\text { inviting students with disabilities to meet with me to } \\
\text { discuss their learning needs. }\end{array}$ & 1 & 2 & 3 & 4 & 5 & 6 \\
\hline $\begin{array}{l}\text { 6. I have attended specialized training to acquire } \\
\text { knowledge about students with learning disabilities } \\
\text { and/or how to teach them. }\end{array}$ & 1 & 2 & 3 & 4 & 5 & 6 \\
\hline $\begin{array}{l}\text { 7. I am aware of assistive technology that students } \\
\text { with learning disabilities can use to improve their } \\
\text { performance in my course. }\end{array}$ & 1 & 2 & 3 & 4 & 5 & 6 \\
\hline
\end{tabular}


Appendix, cont'd

8. Tests and other assessments that I administer in my courses are created with the diverse learning needs of students in mind.

9. If I have a question about a student with a learning disability or their accommodation plan I would go to the Disability Services Office to seek support.

10. I spend a disproportionate amount of time making teaching/testing accommodations and assisting students with disabilities in my courses.

11. Providing classroom and testing accommodations to students with learning disabilities is unfair to students without learning disabilities.

\begin{tabular}{|c|c|c|c|c|c|c|c|}
\hline 12. & $\begin{array}{l}\text { I believe I have the skills necessary to teach } \\
\text { students with learning disabilities. }\end{array}$ & 1 & 2 & 3 & 4 & 5 & 6 \\
\hline 13. & $\begin{array}{l}\text { The college is an accessible learning environ-ment } \\
\text { for students with learning disabilities. }\end{array}$ & 1 & 2 & 3 & 4 & 5 & 6 \\
\hline 14. & $\begin{array}{l}\text { When students with learning disabilities use } \\
\text { accommodations it compromises the integrity of the } \\
\text { curriculum. }\end{array}$ & 1 & 2 & 3 & 4 & 5 & 6 \\
\hline 15. & $\begin{array}{l}\text { I believe students with learning disabilities can be } \\
\text { successful at the college level. }\end{array}$ & 1 & 2 & 3 & 4 & 5 & 6 \\
\hline 16. & $\begin{array}{l}\text { Students with learning disabilities may be able to do } \\
\text { the school work using their accommodations but I } \\
\text { am concerned that they will they will have trouble in } \\
\text { the real work place. }\end{array}$ & 1 & 2 & 3 & 4 & 5 & 6 \\
\hline 17. & $\begin{array}{l}\text { I find students with learning disabilities wait until they } \\
\text { are not doing well in class to come and talk to me } \\
\text { and then I question whether they truly have a LD. }\end{array}$ & 1 & 2 & 3 & 4 & 5 & 6 \\
\hline 18. & $\begin{array}{l}\text { Professionals with learning disabilities may be as } \\
\text { effective as professionals without LD in the same } \\
\text { job/ occupation. }\end{array}$ & 1 & 2 & 3 & 4 & 5 & 6 \\
\hline 19. & $\begin{array}{l}\text { Students with a learning disability use it as an } \\
\text { excuse when they are not doing well in my class. }\end{array}$ & 1 & 2 & 3 & 4 & 5 & 6 \\
\hline 20. & $\begin{array}{l}\text { Having students with learning disabilities in the } \\
\text { classroom reduces the quality of the education that } \\
\text { other student receive. }\end{array}$ & 1 & 2 & 3 & 4 & 5 & 6 \\
\hline 21. & $\begin{array}{l}\text { Students with learning disabilities are advocates for } \\
\text { their learning. }\end{array}$ & 1 & 2 & 3 & 4 & 5 & 6 \\
\hline 22. & $\begin{array}{l}\text { I feel that I can get adequate support from Student } \\
\text { Services about students with learning disabilities. }\end{array}$ & 1 & 2 & 3 & 4 & 5 & 6 \\
\hline
\end{tabular}

